\title{
Processing of black pepper (Piper nigrum L.) through solarisation
}

\author{
T. Ganapathi ${ }^{1}$, S.V. Patil* and G. R. Rajakumar ${ }^{2}$ \\ Regional Horticultural Research and Extension Centre (U.H.S.) G.K.V.K., \\ BENGALURU (KARNATAKA) INDIA (Email : sangappavpatil@ gmail.com)
}

\begin{abstract}
Appearance of red or yellow colour in any of the black pepper berries of a spike indicates optimum maturity. During the production of black pepper, harvesting is done at this stage. Open sun drying method is prevailing in Uttara district of Karnataka and in any other parts of the country too. Traditionally, black pepper is sun dried on a floor coated with cow dung slurry resulting in poor quality produce with less per cent recovery, oleoresin, piperine and aroma and ultimately resulting low market price. In CFTRI technique, the pepper berries/spikes are dipped in boiling water for one minute and then sun dried to get a quality produce. However, it is cumbersome and requires skill. An experiment was conducted at Krishi Vigyan Kendra, Sirsi and in farmer's fields of Siddapur Taluk, Uttar Kannada. In $\mathrm{T}_{1}$ and $\mathrm{T}_{4}$ whole spikes and de berried berries were sun dried in open sun on cement floor, respectively. Whereas in $\mathrm{T}_{2}$ and $\mathrm{T}_{5}$ whole spikes and de-berried berries were processed by dipping in hot water for one minute and then sun dried. In $\mathrm{T}_{3}$ and $\mathrm{T}_{6}$ whole spikes and de-berried berries were processed in between polythene sheets (200 gauge) for 23 hours (till they become black) on first day and then sun dried for 3-4 days. The dry weight of the produce was recorded and per cent recovery was worked out. The samples were analysed for physical and chemical characteristics like bulk density, aroma, colour, per cent oil, oleoresin, piperine and moisture at IISR, Calicut. The treatments $\mathrm{T}_{3}$ and $\mathrm{T}_{6}$ recorded higher recovery of dry berries, good colour, higher aroma and higher market price. In large scale studies $\mathrm{T}_{6}$ performed better in recovery as well as quality parameters such as oleoresin and piperine contents.
\end{abstract}

Key Words : Balck pepper, Salarization, Oleoresin, Recovery

View Point Article : Ganapathi, T., Patil, S.V. and Rajakumar, G.R. (2018). Processing of black pepper (Piper nigrum L.) through solarisation. Internat. J. agric. Sci., 14 (1) : 211-214, DOI:10.15740/HAS/IJAS/14.1/211-214.

Article History : Received : 09.08.2017; Revised : 04.12.2017; Accepted : 16.12.2017

\footnotetext{
* Author for correspondence:

${ }^{1}$ Agricultural Research Station, Hanumanamatti, HAVERI (KARNATAKA) INDIA (Email: ganapathimohan@gmail.com)

${ }^{2}$ Department of Natural Resource Management, College of Forestry, Sirsi, UTTARA KANNADA (KARNATAKA) INDIA (Email: rajkumargr@uasd.in)
} 